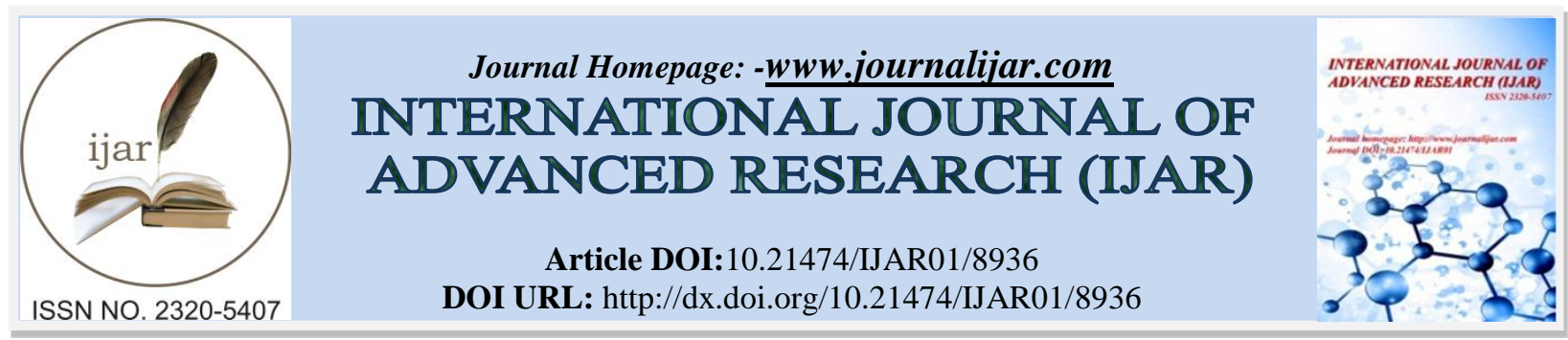

RESEARCH ARTICLE

\title{
IMPACT OF SIMPLIFIED KUNDALINI YOGA AND WALKING AMONG WORKING WOMEN ON JOB SATISFACTION.
}

\section{Ganesan ${ }^{1}$ and Dr. V. Ponnuswamy ${ }^{2}$.}

1. M Phil,PhD Scholar, BharathiarUniversity,Coimbatore.

2. PhD.,Principal, SRMV College of Art \& Science, Coimbatore - 20.

\section{Manuscript Info}

Manuscript History

Received: 22 February 2019

Final Accepted: 24 March 2019

Published: April 2019

Key words:-

Simplified Kundalini Yoga, job satisfaction, impact, walking.

\section{Abstract}

The purpose of the study is to find out the impact of Simplified Kundalini Yoga and walking among working women experimented in psychological variable of job satisfaction. To achieve the purpose of the study 45 working women were selected randomly from Thirupur textile industries as the subjects. The subject's age ranged from 28 to 43 years. The selected subjects were divided into three groups with equal members in each group. The subjects in the Experimental group I underwent on Simplified Kundalini Yoga and the Experimental group II underwent on walking for an hour per day, five days a week for eight weeks the control group were not given any kind of training. Pre and post-test were taken before and after the 8 weeks of training program for analysis and interpreting the data. The results of the study show that Simplified Kundalini Yoga had better impact in the job satisfaction of the subjects than other groups.

Copy Right, IJAR, 2019,. All rights reserved.

\section{Introduction:-}

Physical fitness is the ability to perform vigorous physical activity. The circulatory and respiratory systems are also involved because of their role in supplying muscles with blood and oxygen. To face the modern world today women, they need physical fitness. In day to day of women it is quite difficult to live peacefully because they face lot of changes in their body which affects their muscle strength, endurance, and flexibility. To face that they need to strengthen their body and as well as mentally. Specifically, for working women physical fitness is the ability to endure, bear up, withstand stress and carry on in circumstances where an unfit person could not continue. In order for one to be considered physically fit, the heart, lungs, and muscles have to perform at a certain level for the individual to continue feeling capable of performing an activity.

\section{Objectives Of The Study}

To study that there is any impact of Simplified Kundalini Yoga and walking among working women experimented in psychological variable of job satisfaction. To view that there is any change in psychologically which make them mentally strong it helps in their job.

Corresponding Author:-V. Ganesan.

Address:-M Phil,PhD Scholar, BharathiarUniversity,Coimbatore. 


\section{Statement Of The Problem}

In today's world of women are the one undergo lots of pressure and stress due to problems in their job and family than the men in the same circumstance. To be mentally prepared the yogapay the way for working women to maintain their health and balance them.

\section{Hypothesis}

There was a significant difference in the job satisfactionvariable in-between of Simplified Kundalini Yoga and walking group than the Control group.

\section{Limitations}

1. The working hours varies were not considered.

2. The heredity and genetic problems were not taken into the data.

3. The food habits, life style, sleep etc., of the subjects were not controlled.

4. The tiredness of the subject were affecting training.

\section{Methodology:-}

The 45 working women has been selected as subjects for this project. They underwent pre-test on psychological variables in job satisfaction. Then the subjects were divide into threegroups' namely experimental group I, II and control group with equal members. Experimental group I underwent Practices of Simplified Kundalini Yoga and Experimental group II underwenton walking practices for an hour per day, five days a week for eight weeks. The post-test has been conducted after the eight weeks of practice.

\section{Selected variables for exprement \\ Dependent variables: \\ Psychological variables \\ Job satisfaction}

\section{Aim:}

To determine the extent of job satisfaction of working women.

\section{Material Used:}

Developed by Bubey B.L, Uppal K.K, and Verma S.K

\section{Description:}

The Job Satisfaction Scale consist of 25 statements and it is measured by 5-point scale ranging from 0 to 4 . The working women are allowed evaluate each statement on the basis of their judgment.

1. Strongly agree

2. Agree

3. Undecided

4. Disagree

5. Strongly disagree

\section{Precautions:}

1. The subjects were instructed to respond the statements within 20 minutes.

2. They instructed not to omit any statement.

3. They are allowed to tick only one against each statement.

4. Low scores indicate that satisfaction and high scores indicate that dissatisfaction

\section{Independent Variables}

Practices of

1. Simplified Kundalini Yoga

2. Meditation

3. Walking 


\section{Results And Discussions}

The results of the statistical analysis of the data collected from the pre-test and the post test on Job satisfaction test variable for experimental groups and control group have been presented in Table I

Table I:-analysis Of Covariance Onjob Satisfaction

\begin{tabular}{|c|c|c|r|r|r|r|c|}
\hline TEST & GROUP1 & GROUP2 & GROUP3 & df & \multicolumn{1}{|c|}{ SS } & MOS & F value \\
\hline Pre & 67 & 66.86 & 68.4 & 2 & 21.64 & 10.82 & \multirow{2}{*}{$3.47^{*}$} \\
\cline { 5 - 7 } & & & & 42 & 1579.33 & 37.6 & \\
\hline Post & 62.4 & 66.8 & 68.6 & 2 & 305.2 & 152.6 & \multirow{2}{*}{$6.63^{*}$} \\
\cline { 1 - 4 } & & & & 42 & 965.6 & 22.99 & \\
\hline Adjusted & 62.46 & 66.89 & 68.43 & 2 & 286.31 & 143.15 & \multirow{2}{*}{$6.36^{*}$} \\
\cline { 5 - 7 } & & & & 41 & 922.79 & 22.5 & \\
\hline
\end{tabular}

Significant at 0.05 level of confidence and table value of $F$-ratio for 2 and $42(\mathrm{df})=3.22$ and $41(\mathrm{df})=3.23$

In Table I, the obtained F value onJob satisfaction test6.36 was greater than the table value of 3.23 and hence it was accepted that there were significant differences among the treated groups.

Since significant differences were recorded, the results were subjected to post hoc analysis using Scheffe's Confidence Interval test. The results were presented in Table II.

Table II:-Scheffe's Confidence Interval Test Scores on Job satisfaction

\begin{tabular}{|c|c|c|c|c|}
\hline \multicolumn{3}{|c|}{ Groups } & \multirow{2}{*}{ Mean } & \multirow{2}{*}{ CD } \\
\cline { 1 - 3 } Exp Group1 & Exp Group2 & CNT Group & & \multirow{2}{*}{$2.34^{*}$} \\
\hline 62.46 & 66.89 & & $4.42^{*}$ & \\
\hline 62.46 & & 68.43 & $5.96^{*}$ & \\
\hline & 66.89 & 68.43 & $1.54^{*}$ & \\
\hline
\end{tabular}

The post hoc analysis of obtained ordered adjusted means proved that there were significant differences existed between Simplified Kundalini Yoga group and Walking group (MD: 4.42). There was significant difference between Simplified Kundalini Yoga group and control group (MD: 5.96). There was significant difference between Walking group and control group. (MD: 1.54).

This proved that Simplified Kundalini Yoga has better impact on Job satisfaction than other group.

Fig:-Graph Showing Pre, Post And Adjusted Post-Test Values Of Job Satisfaction

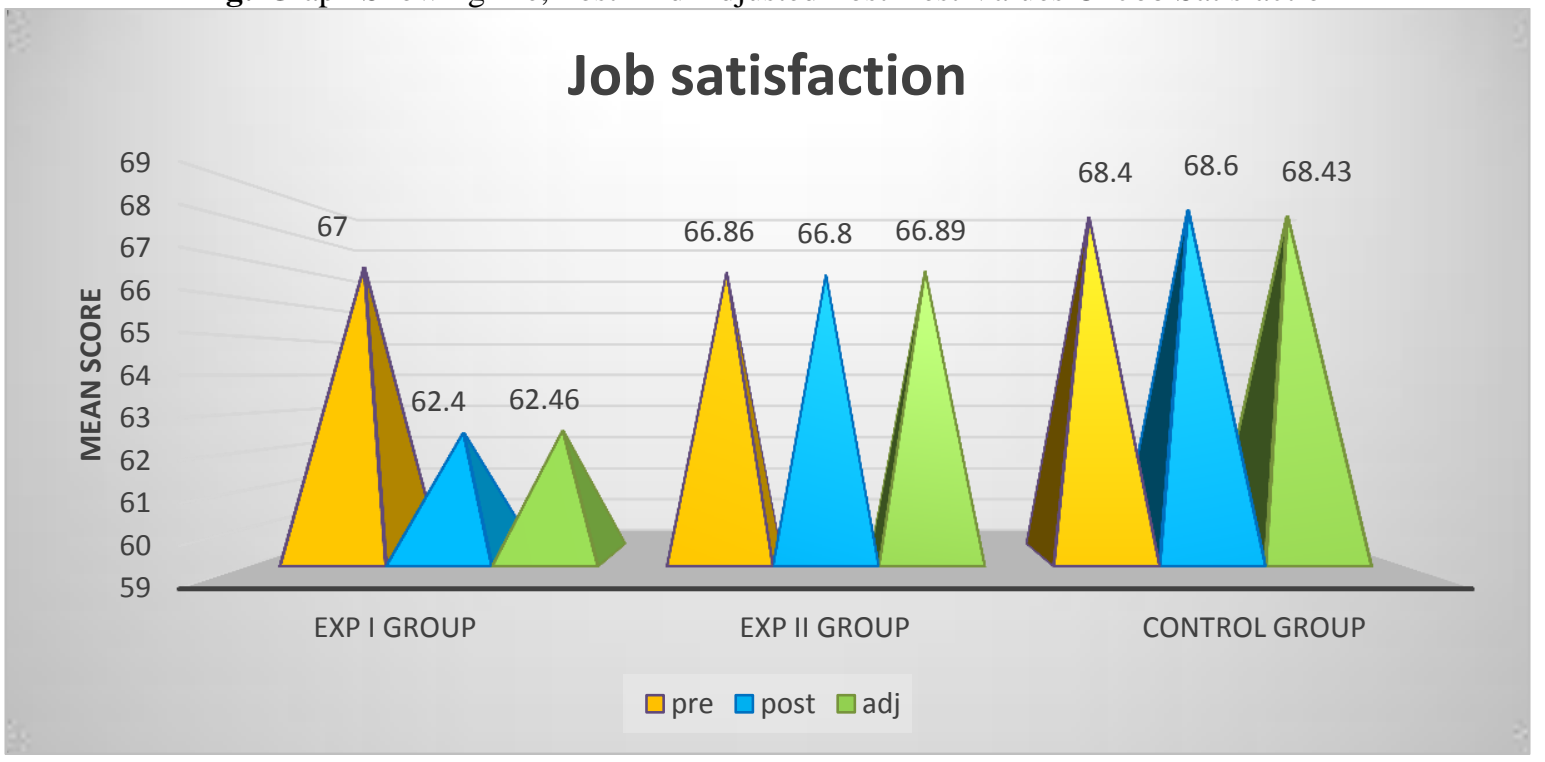




\section{Conclusions:-}

Based on the result of the study the following conclusions were drawn.

1. There was a significant difference between Simplified Kundalini Yoga group and Walking practice group when compared to the control group on psychological variables ofJob satisfaction.

2. Simplified Kundalini Yoga practice was found to be better than Walking practice group and control group in Psychological variables of general Job satisfaction test.

\section{Recommendations:}

1. A similar study may be conducted by selecting other Physical variables as criterion variables.

2. A similar study may be conducted by selecting Performance related variables as criterion variables.

3. A similar study can be conducted for other female age group as subjects.

4. Similar study can be undertaken to analyze the other Psychological and Hematological parameters.

\section{References:}

1. Thathuvagnani Vethathiri Maharishi (1977), "Simplified Physical Exercises", Erode, India: Vethathiri Publications, pp 13-53.

2. Thathuva Gnani Vethathiri Maharishi (1983), "Manavalakkalai Part I" Erode, India: Vethathiri Publications, p.83.

3. Bekiari A., Patsiaouras A, Kokaridas D \&Sakellariou K, "Verbal aggressiveness and state anxiety of volleyball players and coaches", Journal of Psychological reports, Vol. 99, (October, 2006)

4. Rees T, \& Freeman P, "The Effects of Perceived and Received Support on Self- Confidence", Journal of Sports Science, Vol. 25, (November, 2007)

5. Vicar A, "Workplace stress in Nursing", Journal of Advanced Nursing 44(6); (December 2003):633-642. 